\title{
A review on integrated approach for the management of weeds in Cowpea (Vigna unguiculata)
}

\author{
Sinchana J.K. \\ Department of Agronomy, College of Agriculture, Vellayani, Thiruvananthapuram-695522 \\ (Kerala), India \\ Sheeja K RAJ* \\ Department of Agronomy, College of Agriculture, Vellayani, Thiruvananthapuram-695522 \\ (Kerala), India
}

"Corresponding author. Email: sheejakraj70@gmail.com

\section{Article Info}

https://doi.org/10.31018/

jans.v12i4.2386

Received: October 12, 2020

Revised: November 13, 2020

Accepted: November 17, 2020

\section{How to Cite}

Sinchana J.K. and Raj S.K. (2020). A review on integrated approach for the management of weeds in Cowpea (Vigna unguiculata). Journal of Applied and Natural Science, 12(4): 504 - 510. https://doi.org/10.31018/jans.v12i4.2386

\begin{abstract}
Cowpea (Vigna unguiculata) is the most important leguminous crop raised as pulse as well as a vegetable crop in India. The slow initial growth and wider spacing necessitate weed control in the early stages of crop growth. The critical period of crop weed competition in cowpea was 20 to 30 DAS. Season-long crop weed competition resulted in a yield reduction of 40 to 90 per cent in cowpea depending on the intensity of weed infestation, weed flora, season, location, and the climatic condition prevailed. Mulching, manual weeding and stale seedbed are the different cultural methods which can be adopted for weed control in cowpea. Chemical method of weed control is the cheapest and economically viable option for weed control in cowpea. Both Pre-emergence herbicides viz., pendimethalin, diclosulam and imazethapyr and post-emergence herbicides viz., imazethapyr, quizalofop-p-ethyl can be used for weed control in cowpea. Studies revealed that pre-emergence application of herbicide (imazethapyr/pendimethalin or diclosulam) followed by manual weeding or post-emergence application of herbicides (quizalofop -p-ethyl or imazethapyr) or mulching followed by post-emergence application of herbicides (quizalofop-p-ethyl or imazethapyr) were found to be more effective for the broad-spectrum weed control in cowpea. The integrated approach of weed control has resulted in a higher yield, net returns and $\mathrm{B}$ : $\mathrm{C}$ ratio in cowpea.
\end{abstract}

Keywords: Herbicidal method, Manual weeding, Mulching, Nodulation, Stale seedbed

\section{INTRODUCTION}

Cowpea (Vigna unguiculata) is an important pulse crop grown throughout India and Kerala as a grain and vegetable crop. The pods are highly nutritive and are a good source of digestible protein, dietary fiber and vitamin $A$ and $\mathrm{C}$. In addition to this, the pods also contain $\mathrm{Ca}, \mathrm{P}, \mathrm{Na}, \mathrm{K}, \mathrm{Mg}$, $\mathrm{Fe}, \mathrm{Zn}, \mathrm{Mn}$ and $\mathrm{Cu}$ (Gerrano et al., 2017). The initial slow development and wider spacing necessitate weed control in an earlier period of cowpea (Kandasamy, 1999; Osipitan et al., 2016; Sinchana, 2020). The weed infestation has been reported more severe during the rainy season and causes severe yield reduction. The critical period of crop weed competition (CWC) in cowpea was 20 to 30 days after sowing (DAS), this clearly points out the necessity of weed control during the first month of crop growth. The impact of weed interference on cowpea yield depends on the duration and stage at which the crop-weed interference takes place. The season-long competition resulted in 53 to 76 per cent yield reduction in cowpea (Gupta et al., 2016). The review of the literature regarding the yield loss caused by weeds in cowpea, nutrient uptake by crop and weed, critical period of CWC, weed flora in cowpea, effect of the different methods on weed control in cowpea, the effect of weed management practices on enzyme activity, nodulation, physiological parameters and economics are elaborated in this paper.

\section{YIELD LOSS CAUSED BY WEEDS IN COWPEA}

Vegetable cowpea is found to be infested by a broad spectrum of weeds, especially in the early stages. On account of their initial slow growth, cowpea is often subjected to weed infestation. Reduction in yield depends on the weed species, weed density and weed dry weight (Osipitan and Dille, 2017 and Sinchana, 2020). Wilson et al. (1980) opined that for every 100 $\mathrm{kg}$ weed dry weight, yield reduction of $208 \mathrm{~kg} \mathrm{ha}^{-1}$ occurred in cowpea. In cowpea, more than 96 per cent yield reduction was reported due to weed infestation (Amador-Ramirez et al., 2001).

Tripathi and Singh (2001) stated that in cowpea, weeds caused 82 per cent reduction in yield. Muham- 
mad et al. (2003) reported that weed infestation reduced the yield by 82 per cent, however, if weeds were controlled up to 45 DAS, a significant increase in pod yield was observed in cowpea. Li et al. (2004) opined that due to weed infestation yield loss in cowpea has been as high as 41 to 80 per cent but significant increase in yield was observed if weeds were controlled up to 45 DAS. Freitas et al. (2009) reported 90 per cent reduction in final crop stand, the number of pods per plant and grain yield due to weed interference in cowpea Inadequate weed control caused 40 to 80 per yield reduction in cowpea (Sunday and Udensi, 2013). Depending on the cultivar and agro-ecological condition yield losses in cowpea ranged from 25 to 76 per cent (Gupta et al., 2016; Osipitan et al., 2016; Ugbe et al., 2016). Sinchana (2020) reported that season-long weed competition resulted in 59 per cent yield reduction in bush-type vegetable cowpea.

\section{CRITICAL PERIOD OF WEED CONTROL}

The critical period of weed control (CPWC) is the shortest duration of crop growth where crop must be kept weed-free for preventing the yield loss due to weed competition (van Acker et al., 1993). If the growth of the weed were checked during CPWC, the potential yield of crops could be maximized (Mishra, 1997; Tewari, 1999).

Medrano et al. (1973) revealed that 20 to 40 DAS was the CPWC in cowpea. Akinyemiju and Echendu (1987) observed that CPWC in cowpea varies from 10 to 45 DAS, and in the rainy season, it may extend up to harvest stage (Patel et al., 2002). Akobundu (2005) observed that initial 3 to 4 weeks were critical for weed competition in cowpea. Freitas et al. (2009) revealed that the CPWC in cowpea was 11 to 35 DAS. Sunday and Udensi (2013) opined that during the first three to four weeks of crop growth, weed infestation would adversely affect the crop yield in cowpea. Gupta et al. (2016) opined that 20 to 30 DAS was the CPWC in cowpea and the presence of weeds during that period caused severe yield reduction. Cowpea is sensitive to weed competition especially at the early stage of crop development and the period from 14 to 40 DAS was considered to be critical for crop weed competition (Osipitan et al., 2016). However, Yadav et al. (2018) reported that critical period of crop-weed competition in forage cowpea (Vigna unguiculata) was found to be between 25-57 days and also reported that keeping the crop weed-free for first 60 days resulted in higher net returns and $\mathrm{B}$ : $\mathrm{C}$ ratio.

\section{WEED FLORA IN COWPEA}

Weed flora in cowpea varies with the region, soil and climatic conditions. Akinyemjju and Echendu (1987) conducted a field experiment in Nigeria and revealed that major weed flora associated with cowpea was Imperata cylindrica, Talinum triangulare, Euphorbia heterophylla, Synedrella nodiflora, Ageratum co- nyzoides, Spigelia anthelmia, Amaranthus spp, Ipomea spp and Cynodon dactylon. Singh and Prasad (1987) observed that cowpea field was infested with various weeds like Eragrostis japonica (12.5\%), Cyperus rotundus (15\%), Boerhavia diffusa (22.7\%) and Echinochloa colonum (32.1\%). Mathew and Sreenivasan (1998) revealed that during summer season cowpea field was dominated by dicotyledon weeds and during Kharif season, grasses and sedges were dominated. Tripathi and Singh (2001) mentioned that major weed flora in cowpea was Sorghum halepense (6.9\%), Echinochloa crusgalli (8.4\%), Cyperus rotundus (12.8\%), Gnaphalium indicum (14.4\%), Eleusine indica (15.7\%) and Dactyloctenium aegyptium (41.8\%). Chattha et al. (2007) conducted field experiments in Islamabad under rainfed conditions revealed that Trianthema monogyna, Cyperus rotundus, Sorghun halepense, Digera arvensis, Echinochloa coloana and Cynodon dactylon were the predominant weed flora in the cowpea field. Kumar and Singh (2017) revealed that Cynodon dactylon, Echinochloa colona Brachiaria spp., Leucas aspera, Commelina nudiflora, Portulaca oleracea, Phyllanthus niruri, Tridax procumbens and Cyperus rotundus were the major weed flora found in association with cowpea. Trianthema monogyana, Commelina benghalensis, Digera arvensis, Cyperus rotundus and Echinochloa cloana were the major weeds found in association with cowpea (Yadav et al., 2018). Studies conducted at Coconut Research Station, Balaramapuram, Kerala, Sinchana (2020) observed that Setaria barbata, Digitaria sanguinalis, Spermacoce latifolia, Alternanthera sessilis, Phyllanthus niruri, Synedrella nodiflora and Cyperus rotundus were the major weed flora in bushtype vegetable cowpea.

\section{MULCHES FOR WEED CONTROL IN COWPEA}

Mulching apart from adding organic matter to the soil, prevents soil erosion and decreases the weed population in initial crop growth stage by hindering the weed emergence (Monquero et al., 2009; Pereira et al., 2011;). Mulches suppress the weeds by blocking the sunlight or creating the environmental conditions which will prevent the germination, emergence and subsequent growth of weeds.

Organic mulches reduce tillage operations and are more popular in cropping systems (Bilalis et al., 2003). They play an important role in enhancing the crop yield by reducing the soil temperature, increasing the soil moisture level and lowering the weed density (Sinkeviciene et al., 2009; Mahmood et al., 2015).

Lamini et al. (2011) opined that mulching with organic materials to a thickness of $10 \mathrm{~cm}$ was found effective in controlling the weeds and degrade quickly. Straw, perennial weeds, water-hyacinth, crop residues obtained from perennial crop residues of banana, sugarcane straw, sugarcane bagasse, sawdust, newspaper and shredded paper can be used as organic mulches 
(Monks et al., 1997: Silva et al., 2015).

Pullaro et al. (2006) opined that when plant residue is used as mulch material, it indirectly reduces the weed seed bank and thereby reduces the weed emergence. Maria Junior et al. (2018) revelated that mulching significantly reduced the density of Cyperus rotundus, Digitaria horizontalis and Galinsoga parviflora in cowpea. Mulching with dried banana leaf @ 10 t ha $^{-1}$ was found effective in controlling the grasses, sedges and broadleaf weeds in cowpea Sinchana (2020).

\section{STALE SEED BED FOR WEED CONTROL IN COWPEA}

Stale seedbed is a way by which weeds seeds were allowed to germinate by giving pre-sowing irrigation and emerged weeds were destroyed using non-selective herbicides or by pre-plant tillage practices (Gnanavel and Kathiresan, 2014; Singh, 2014). The method of seedbed preparation, weed species present, the method adopted to kill the emerged weeds, environmental condition and the duration influence the success of stale seedbed (SSB) in controlling the weeds (Singh, 2014).

Stale seedbed significantly reduced the viability of weed seeds like Digitaria sanguinalis, Poa annua and Eleusine indica in the top two $\mathrm{cm}$ soil layer (Standifer, 1980). Riemens et al. (2007) opined that SSB with the mechanical method of weed control effectively reduced the density of weeds and was equally effective to the chemical method. Sinchana (2020) reported that SSB significantly reduced the total density and dry weight of weeds in cowpea at 15, 30 and 45 DAS and it was also reported that SSB + mulching with dried banana leaf followed by quizalofop-p-ethyl registered the lowest weed index and the highest weed control efficiency and green pod yield.

\section{MANUAL WEEDING FOR WEED CONTROL IN COWPEA}

Manual weeding is the most common method adopted by the farmers to remove the weeds in vegetable cowpea. Due to the high wage rate, non-availability of labourer's at the right time and aberrant weather conditions limits its efficacy.

Adigun et al. (2014) reported that hand-weeding after complete ground coverage and during the reproductive stage caused physical injury to the crop plant and resulted in a significant reduction in pod yield in cowpea. In cowpea, weeds can be effectively managed by hand weeding at third and sixth weeks after sowing (WAS) (Anonymous, 2014). Kujur et al. (2015) observed that hand weeding at 20 and 40 DAS registered the highest number of pods per plant and seed yield of $1016.66 \mathrm{~kg} \mathrm{ha}^{-1}$ in cowpea. Hand weeding and intercultural operations at 20 and 40 DAS recorded grain yield comparable with that of the weed-free check (Kumar and Singh, 2017). Kumar et al. (2017) reported that two-hand weeding followed by one inter- cultural operation recorded the highest yield in cowpea $\left(1581.02 \mathrm{~kg} \mathrm{ha}^{-1}\right)$ and also found that yield increased was to a tune of 25.2 per cent as compared to the weedy check. Two hands weeding at two and five weak after emergence (WAE) recorded the lowest weed dry weight, higher number of nodules per plant and yield components in cowpea (Mekonnen and Dessie., 2017). However, Sinchana (2020) reported that compared to hand weeding twice at 20 and 40 DAS, pre-emergence application of diclosulam $12.5 \mathrm{~g}$ ha $^{-1}$ followed by hand weeding or quizalofop-p-ethyl at 25 DAS registered the lowest density and dry weight of weeds in bush-type vegetable cowpea.

\section{HERBICIDAL METHOD OF WEED CONTROL IN COWPEA}

Chemical weed control is the cheapest and economically viable option for weed control in crops due to high efficacy, large area coverage, easiness in the application and in areas where intercultural operations is not possible due to shortage of labour. It reduces the cost of tillage operations for weed control, kills the weeds in situ without any dissemination of vegetative propagules and effectively controls brush weeds and perennials. Gianessi and Reigner (2006) reported that the chemical method of weed control reduced the cost of production of crops by 20 per cent. For the best results, herbicides should be integrated with other methods; it should not be considered as an alternative to other weed control methods. The efficacy of herbicides depends on the right selection of herbicide, method of application and application at the recommended dose. Fontes et al. (2010) opined that the chemical method of weed control was cost-effective as compared to the mechanical method, especially hand weeding. Madukwe et al. (2012) observed that in cowpea, herbicide application at two to three-leaf stage recorded the highest plant height, number of pods per plant and test weight as compared to hand weeding treatment.

Based on the time of herbicide application, herbicides are classified into pre-emergence and postemergence herbicides. Pre-emergence herbicides are usually applied before the emergence of crop and weed, prevent the germination of weed seeds by inhibiting the root growth, shoot growth or both. It will remain in the soil for a substantial period, usually 8 to 12 weeks. Post-emergence herbicides are herbicides applied after the crop and weed emergence. Imazethapyr and quizalofop-p-ethyl are the most commonly applied post-emergence herbicides in cowpea. Imazethapyr comes under imidazoline group, and quizalofop-p-ethyl comes under aryloxyphenoxypropionic acid group. Both the herbicides exhibited low to no phytotoxicity symptoms in cowpea as applied as a post-emergence herbicide. Singh et al. (2014) opined that to reduce the human labour for weeding and also to control the second flush of weeds, and there is a 
need for using post-emergence herbicides in crops. Pendimethalin is the widely used pre-emergence selective herbicide for weed control in cowpea. It prevents cell division and cell elongation and inhibits shoot and root growth in susceptible species. Jaibir et al. (2004) reported that pre-emergence application of pendimethalin $1 \mathrm{~kg} \mathrm{ha}^{-1}$ alone or followed by hand weeding at 30 DAS recorded the lowest density and dry weight of weeds in fodder cowpea. Preemergence application of pendimethalin alone @ 0.75 $\mathrm{kg} \mathrm{ha}^{-1}$ or followed by hand hoeing at 20-25 DAS was found very effective for the broad-spectrum control of weeds in cowpea (Hanumanthappa et al., 2012). Usman (2013) revealed that pre-emergence pendimethalin@ $3.5 \mathrm{~L} \mathrm{ha}^{-1}$ followed by hand weeding 6 weeks after sowing registered higher grain yield and lower density of weeds.

Diclosulam, a pre-emergence broad-spectrum herbicide belongs to the group triazalopyrimidine inhibits acetolactate synthase enzyme in susceptible species. It has been reported that half-life of diclosulam varies from 16 to 87 days, according to the prevailed environmental conditions (Lavorenti et al., 2003). The adsorption and degradation of diclosulam in the soil depend on the soil moisture and organic matter content (Rodrigeus and Almeida, 2011). Sinchana (2020) reported that pre-emergence diclosulam @125 g ha-1 followed by quizalofop-p-ethyl or hand weeding was very effective in reducing the density and dry weight of weeds in bush-type vegetable cowpea. It was also reported the pre-emergence application of diclosulam did not have any inhibitory effect on nodulation in cowpea. Imazethapyr is a standard commercial herbicide having both pre-emergence and post-emergence action. Pre-emergence imazethapyr did not have any adverse effect, but post- emergence application may cause a minor impact on yield due to stunting and slight chlorosis (Wilson and Miller, 1991). Gupta et al. (2016) observed that imazethapyr +imazemox $40 \mathrm{~g} \mathrm{ha}^{-1}$ recorded the highest seed yield and weed control efficiency in cowpea. Yadav et al. (2016) reported that imazethapyr @ $75 \mathrm{~g} \mathrm{ha}^{-1} \mathrm{fb}$ one hand weeding at 40 DAS was the best treatment for controlling weeds in fodder cowpea. Application of imazethapyr $75 \mathrm{~g} \mathrm{ha}^{-1}$ or quizalofop-p-ethyl @ $40 \mathrm{~g} \mathrm{ha}^{-1}$ at 20-25 DAS fb one hand weeding and one intercultural operation at 40-45 DAS registered lower weed dry weight in cowpea (Kumar and Singh, 2017). Sinchana (2020) reported that mulching with dried banana leaf @10 t ha ${ }^{-1}$ followed by imazethapyr $50 \mathrm{~g} / \mathrm{ha}^{-1}$ at 25 DAS significantly reduced the density of sedges, BLW and grasses in cowpea than that of postemergence application of imazethapyr alone at $50 \mathrm{~g}$ ha $^{-1}$ on 15 DAS.

Quizalofop-p-ethyl belonging to aryloxyphenoxypropionic acid group is the commonly used post-emergence grass effective herbicide for annual and perennial grassy weed control in pulses. In vegetable cowpea, quizalofop-ethyl @ $0.05 \mathrm{~kg} \mathrm{ha}^{-1} \mathrm{fb}$ hand weeding at 40 DAS significantly reduced the weed density and DMP (Sah et al., 2015). A study conducted by Sinchana (2020) in bush-type vegetable cowpea revealed that mulching with dried banana leaf @ $10 \mathrm{t} \mathrm{ha}^{-1}$ followed by quizalofop-p-ethyl @ $50 \mathrm{~g} \mathrm{ha}^{-1}$ at 25 DAS or preemergence application of diclosulam @ $12.5 \mathrm{~g} \mathrm{ha}^{-1}$ followed by quizalofop-p-ethyl @ $50 \mathrm{~g} \mathrm{ha}^{-1}$ at 25 DAS recorded significantly lower density and dry weight of weeds and higher grain yield than that of the weedy check.

\section{EFFECT OF WEED MANAGEMENT PRACTICES ON NODULATION IN COWPEA}

Gupta and Gupta (1983) observed that grass mulching reduced the soil temperature and increased the nodulation in pulses. The highest number of nodules per plant was noticed in organic mulch compared to black polyethylene mulch in cowpea (Dukare et al., 2017). Compared to herbicides, S Metalochlor and Pendimethalin, hand weeding and hoeing at 21 days after emergence recorded higher number of nodules in cowpea (Mekonnen and Dessie, 2017). However, Sinchana (2020) reported that pre-emergence application of diclosulam @ $12.5 \mathrm{~g} \mathrm{ha}^{-1}$ recorded higher number of nodules in cowpea compared to hand weeding treatment and mulching with dried banana leaf @ $12 \mathrm{t} \mathrm{ha}^{-1}$.

\section{EFFECT OF WEED MANAGEMENT PRACTICES ON NET RETURNS AND B: C RATIO IN COWPEA}

Economic assessment of weed control treatments is of utmost importance for its acceptance in farmers level. High weed control efficiency (WCE) coupled with costeffectiveness, should be the criterion for the selection of the best weed management treatment (Khaliq et al., 2011).

Imazethapyr @ $40 \mathrm{~g} \mathrm{ha}^{-1}$ recorded the highest net return (₹ 24,718) and B:C ratio (3.46) in cowpea grown under rainfed condition (Gupta et al., 2016). Kumar and Singh (2017) also revealed that post emergence quizalofop-p-ethyl + one hand weeding + one intercultural operation recorded the highest net return (₹23,709) and B: C ratio (4.21) in cowpea.

Among the weed management practices, two hands weeding at 25 and 40 DAS recorded higher gross income (₹81,320.50 ha-1), net return (₹ 31,388 $\mathrm{ha}^{-1}$ ) and $\mathrm{B}: \mathrm{C}$ ratio (1.63) in vegetable cowpea (Patil et al., 2014). Kujur et al. (2015) reported that hand weeding at 20 and 40 DAS recorded the highest net return in cowpea. Pre-emergence application of pendimethalin $1.0 \mathrm{~kg} \mathrm{ha}^{-1}$ followed by hand weeding and hoeing at 35 DAE was proved to be the most profitable weed management practice in cowpea (Mekonnen and Dessie, 2017). Osipitan et al. (2018) reported that preemergence application of herbicide codal (S metolachlor $16 \%$ w/w + prometryn $25 \%$ w/w) @ $2.4 \mathrm{~L}$ ha $^{-1}$ followed by hand weeding 6 weeks after planting recorded the highest yield and profit in cowpea. Mulch- 
ing with dried banana leaf @ $10 \mathrm{t} \mathrm{ha}^{-1}$ followed by post -emergence application of quizalofop-p-ethyl or imazethapyr @ $50 \mathrm{~g} \mathrm{ha}^{-1}$ recorded higher net returns and $\mathrm{B}$ : $\mathrm{C}$ ratio than hand weeding twice at 20 and 40 DAS in bush-type vegetable cowpea (Sinchana, 2020).

\section{Conclusion}

Initial slow growth and wider spacing necessitate weed management in cowpea. Poor management of weeds results in significant yield reduction in cowpea. Nonchemical methods viz., mulching, stale seedbed and manual method of weeding can be adopted for weed control in cowpea. However, the chemical method of weed control is the smartest viable option. Both premergence herbicides (pendimethalin, diclosulam and imazethapyr) and post-emergence herbicides (imazethapyr, quizalofop-p-ethyl) can be effectively utilized for weed control in cowpea (Vigna unguiculata). A combination of chemical and non-chemical methods will give better results than going for a chemical method of weed control alone. Adoption of such weed management practices results in higher yield and better returns.

\section{Conflict of interest}

The authors declare that they have no conflict of interest.

\section{REFERENCES}

1. Adigun, J., Osipitan, A.O., Lagoke, S.T., Adeyemi, R.O. and Afolami, S.O. (2014). Growth and yield performance of cowpea (Vigna unguiculata (L.) Walp) as influenced by row-spacing and period of weed interference in SouthWest Nigeria. Journal of Agricultural Science 6 (4): 188198. DOI: 10.5539/jas.v6n4p188

2. Akinyemiju, O. A. and Echendu, T. N. C. (1987). Influence of tillage method and pre-emergence herbicide on weeds control in cowpea (Vigna unguiculata (L.) Walp). Crop Protection 6: 289-294.DOI: 10.1016.0261-2194(87)90057-3

3. Akobundu, I. O. (2005). Chemical weed control in cowpea and soybean in Southern Nigeria. In: Zene Symposim surle Desherbage de cultures tropicales. pp 475-482.

4. Amador-Ramirez, M. D., Wilson, R. G., and Martin, A. R. (2001). Weed control and dry bean (Phaseolus vulgaris) response to in-row cultivation, rotary hoeing and herbicides. Weed Technology, 15: 429-436. DOI: 10.1614/0890 0 37X(2001)015[0429:WCADBP]2.0.Co;2

5. Anonymous (2014). Package of Practices for Kharif Crops of Punjab. Punjab Agricultural University, Ludhiana, India.

6. Bilalis, D., Sidiras, N., Economou, G., and Vakali, C. (2003). Effect of different levels of wheat straw soil surface coverage on weed flora in Vicia faba crops. Journal of Agronomy and Crop Science., 189: 233-241. DOI: 10.1046/j.1439-037X.2003.00029.x.

7. Chattha, M.R., Jamil, M. and Mahmood, T.Z. 2007. Yield and yield components of mungbean as affected by various weed control methods under rainfed conditions of Pakistan. International Journal of Agriculture and Biology, 9(1): 114-119.

8. Dukare, A., Kale, S., Kannaujia, P., Indore, N., Mahawar, M. K., Singh, R. K., and Gupta, R. K. (2017). Root devel- opment and nodulation in cowpea as affected by application of organic and different types of inorganic/plastic mulches. International Journal of Current. Microbiology and Applied. Sciences, 6:1728-1738.DOI: 10.20546/ ijcma s.2017.611.209

9. Fontes, J. R. A., Goncalves, J. R. P., and Morais, R. R. de. (2010). Cowpea tolerance to oxadiazon. Indian Journal of Weed Sciences 40 (1): 110-115.

10.Freitas, F. C. L., Medeiros, V. F. L. P., Grangeiro, L. C., Silva, M. G. O., Nascimento, P. G. M. L., and Nunes, G. H. (2009). Weed interference in cowpea. Indian Journal Weed Sciences 27 (2): 241-247.

11.Gerrano, A.S., van Rensberg, W.S.J., and Adebola, P. (2017). Nutritional composition of immature pods in selected cowpea [Vigna unguiculata (L.) Walp] genotypes in South Africa. Australian Journal of Crop Science 11 (02): 134-141. DOI:10.21475/ajcs.17.11.02. p72

12.Gianessi, L. and Reigner, N. (2006). Barriers to widespread conversion from chemical pest control to nonchemical methods in U.S. agriculture. In: Proceedings of the Third International Conference on the Future of Agriculture. Sacramento, California.

13.Gnanavel, I. and Kathiresan, R. M. (2014). Eco-friendly weed control options for sustainable agriculture- a review. Agricultural Reviews 35 (3): 172-183.

14.Gupta, J. P. and Gupta, G. N. (1983). Effect of grass mulching on growth and yield of legumes. Agricultural Water Management 6 (4): 375-383. DOI: 10.1016/03783774(83)90056-2

15.Gupta, K. C., Gupta, A. K., and Saxena, R. (2016). Weed management in cowpea [Vigna unguiculata (L.) Wasp.] under rainfed conditions. International Journal of Agricultural Science 12 (2): 238-240.

16. Hanumanthappa, D. C. Mudalagiriyappa, Rudraswamy, Kumar, G. N. V. and Padmanabha, K. (2012). Effect of weed management practices on growth and yield of cowpea (Vigna unguiculata L.) under rainfed conditions. Crop Research 44 (1\& 2): 55-58

17.Jaibir, T., Singh, H.B., Vivek., and Tripathi, S.S. (2004). Integrated weed management in intercropping of mung bean (Vigna radiata) and cowpea fodder (Vigna unguiculata) with pigeon pea (Cajanus cajan) under Western U.P. condition. Indian Journal of Weed Science 36: 133-134.

18.Kandasamy, O. S. (1999). Effect of herbicides with and without manual weeding on weeds and yield of rainfed pigeonpea (Cajanus cajan L. Millsp.). Legume Research 22(3): 172-176.

19.Khaliq, A., Riaz, M. Y., and Matloob, A. (2011). Bioeconomic assessment of chemical and non-chemical weed management strategies in dry seeded fine rice (Oryza sativa L.). Journal of Plant Breeding and Crop Science 3 (12): 302-310.

20.Kujur, A., Bhadauria, N., and Rajput, R. L. (2015). Effect of weed management practices on seed yield and nutrient (NPK) uptake in cowpea. Legume Research 38 (4): 555557.DOI: 10.5958/0975-0571.2015.00136.8

21.Kumar, N., Hazra, K. K., and Nadarajan, N. (2017). Efficacy of pre and post-emergence herbicides in rainy season green gram (Vigna radiata). Indian Journal of Agricultural Science 87 (9): 1219-1224.

22.Kumar, P. and Singh, R. (2017). Integrated weed management in cowpea (Vigna unguiculata (L.) Wasp.) under rainfed conditions. International Journal of Current Microbiology and Applied Sciences, 6(3): 97-101. DOI: 10.205 46/ijcmas.2017.603.010 
23.Lamini, W. T., Mc Gourty, G. T., and Thrupp, L. A. (2011). In: Mc Gourty, G. (Ed.), Weed management for organic vineyards. Organic Winegrowing Manual. University of California, Agriculture and Natural Resources, Richmond, pp. 69-82.

24.Lavorenti, A., Rocha, A. A., Prata, F., Regitano, J. B., Tornisielo, V. L., and Pinto, O. B. (2003). Behaviuor of diclosulam in samples of a dystrophic red latosol under no tillage and conventional tillage. The Revista Brasileira de Ciência do Solo 27:183-190.

25.Li, R. Z., Guidong, Z., Yumei., and Zhanzh, X. (2004). Damage loss and control technology of weeds in cowpea field. Weed Science 2: 25-6.

26.Madukwe, D. K., Ogbuehi, H. C., and Onuh, M. O. (2012). Effect of weed control method on the growth and yield of cowpea (Vigna unguiculata (L) Walp) under rainfed condition Owerri. American-Eurasian Journal of Agricultural and Environmental Science 12 (11): 1426-1430.

27.Mahmood, A., Ihsan, M. Z., Khaliq, A., Hussain, S., Cheema, Z. A., Naeem, M., Daur, I., Hussain, H. A., and Alghabari, F. (2015). Crop Residues Mulch as Organic Weed Management Strategy in Maize. Clean-Soil, Air, Water 44 (3): 317-324. DOI: 10.1002/clen.201500155

28.Maria Junior, S.de O., de Andrade,J.R., Reis, L.S., deAndrade, L.R., and Goncalves, A.C. de M. (2018). Soil management and mulching for weed control in cowpea. www.agro.ufg.br/pat-Pesq-Agropec.Trop.Goiania. 48 (4):453-460

29.Mathew, G. and Sreenivasan, E. (1998). Effect of weed control methods on yield and economics of rain-fed and rice fallow summer cowpea. Madras Agricultural Journal 85: $50-52$

30.Medrano, S. C., Arila, L. R., and Villasmil, P. J. J. (1973). Determination of the critical period weed competition in cowpea. Revista de la faculad de Agronomy Universidad de zulia. 2: 7-13.

31.Mekonnen, G. and Dessie, M. (2017). Nodulation and yield response of cowpea (Vigna unguiculata) to integrated use of planting pattern and herbicide mixtures in Wolla, Northern Ethiopia. Agricultural Research \& Technology 7 (2):555710. DOI:10.19080/ARTOAJ.009.OAJ.20 17.07.555710

32.Mishra, J. S. (1997). Critical period of weed competition and losses due to weeds in major field crops. Farmers Parliament XXXIII 6:19-20.

33.Monks, D. C., Monks, D. W., Basden, T., Selders, A., Poland, S., and Rayburn, E. (1997). Soil temperature, soil moisture, weed control, and tomato (Lycopersicon esculentum) response to mulching. Weed Technology 11. 561-566. DOI: $10.1017 / \mathrm{S} 0890037 \mathrm{X} 00045425$

34.Monquero, P. A., Amaral, L. R., Inácio, E. M., Brunhara, J. P., Binha, D. P., Silva, P. V., and Silva, A.C. (2009). Effect of green manures in suppressing weed species. Planta Daninha 27 (1): 85-95.

35.Muhammad, R. C., Muhammad, J., and Tahira, Z. M. (2003). Yield and yield components of cowpea as affected by various weed control methods under rain fed conditions of Pakistan. International Journal of Agriculture and. Biology 9 (1): 120-124.

36.Osipitan, O. A., Adigun, J. A., and Kolawole, R. O. (2016). Row spacing determines critical period of weed control in crop: Cowpea (Vigna unguiculata) as a case study. Azarian Journal of Agriculture 3 (5): 90-96.

37. Osipitan, O. A., and Dille, J. A. (2017). Fitness Outcomes Related to Glyphosate Resistance in Kochia (Kochia scoparia): What Life History Stage to Examine? Frontiers in Plant Science. DOI: 10.3389/fpls.2017.01090

38.Patel, M. M., Patel, A. I., Patel, I. C., Tikka, S. B. S., Henry, A., Kumar, D., and Singh, N. B. (2002). Weed control in cowpea under rain-fed conditions. In: Proceedings of the National Symposium on Arid Legumes, for Food Nutrition Security and Promotion of Trade. Hisar, India. Advances in Arid Legumes Research. pp. 203-206.

39.Patil, B.C., Padanad, L.A., Yashvantkumar, K.H., Soumya, S., and Ravi, L. (2014). Efficacy and economics of integrated weed management in vegetable cowpea [Vigna unguiculata (L.) Walp]. Agriculture Update 9 (1): 124-127.

40.Pereira, R. A., Alves, P. D. C., Corrêa, M. P., and Dias, T. D. S. (2011). Black-oats and millet cover influence on weed community and soybean yield. Brazilian Journal of Agriculture Science 6 (1): 1-10

41.Pullaro, T. C., Marino, P. C., Jackson, D. M., Harrison, H.F., and Keinath, A.K. (2006). Effects of killed cover crop mulch on weeds, weed seeds, and herbivores. Agriculture Ecosystems and Environment 115:97-104.

42.Riemens, M. M., Van Der Weide, R.Y., Bleeker, P. O., and Lotz, L. A. P. (2007). Effect of stale seed bed preparations and subsequent weed control in lettuce (cv. Iceboll) on weed densities. Weed Research 47 (2): 149156.DOI:10.1111/j.1365-3180.2007.0055,x

43.Rodrigeus, B. N. and Almeida, F. S. 2011. Herbicides (6 $6^{\text {th }}$ eds). Londrina. production independent. 697p.

44.Sah,D., Dubey, R. K., Singh, V., Debnath, P., and Pandey, A.K. (2015). Study of weed management practices on growth, root nodulation and yield components of vegetable cowpea [Vigna unguiculata (L.) Walp.]. The Bioscan 10 (1): 421-424.

45.Silva, P. V., Monquero, P. A., Silva, F. B., Bevilaqua, N. C., and Malardo, M. R. (2015). Influence of sugarcane straw and sowing depth on the emergence of weed species. Planta Daninha 33 (3): 405-412.

46.Sinchana, J.K. (2020). Integrated weed management in bush type vegetable cowpea (Vigna unguiculata subsp. unguiculata). M. Sc. (Ag) thesis, Kerala Agricultural University, Thrissur, 181p.

47.Singh, G., Aggarwal, N., and Ram, H. (2014). Efficacy of post-emergence herbicide imazethapyr for weed management in different mung bean cultivars. Indian Journal of Agriculture Science 84: 540-543.

48.Singh, P. P. and Prasad, R. (1987). Studied on chemical weed control in fodder cowpea. Indian Journal of Agronomy 32 (3): 280-281.

49.Singh, R. (2014). Weed management in major kharif and rabi crops. National Training on Advances in Weed Management. pp. 31-40.

50.Sinkeviciene, A., Joduagiene, D., Pupaliene, R., and Urboniene, M. (2009). The influence of organic mulches on soil properties and crop yield. Agronomy Research 7 (1): 485-491.

51.Standinfer, L. C. (1980). In: Proceedings of the $33^{\text {rd }}$ Annual Meeting of the Southern Weed Science Society. p.254.

52.Sunday, O. and Udensi, U. E. 2013. Evaluation of preemergence herbicides for weed control in cowpea (Vigna unguiculata (L.) Walp.) American Journal of Experimental Agriculture 3 (4): 767-779.DOI: 10.9734/ajea/2013/3902

53.Tewari, A. N. (1999). Status of weed management research in intercropping in India - An overview. In: Proceedings of the seventeenth Asian - Pacific Weed Science Society Conference, Bangkok, Thailand, pp. 266-275. 
54.Tripathi, S. S. and Singh. (2001). Critical period of weed competition in summer cowpea (Vigna unguiculata L.). Indian Journal of Weed Science 33: 67-8.

55.Ugbe, L. A., Ndaeyo, N. U., and Enyong, J. F. (2016). Efficacy of selected herbicides on weed control, cowpea (Vigna unguiculata L. Walp) performance and economic returns in Akamkpa, Southeastern Nigeria. International Journal of Research in Agriculture and Forestry 19: 1927.

56.Usman, I. (2013). Effect of pre emergence herbicides on weed control and performance of cowpea in Samaru. Journal of Agricultural Sciences (Sri Lanka) 8(2): 76-81.

57.van Acker, R. C., Swanton, C. J., and Weise, S. F. (1993). The critical period of weed control in soybean (Glycine max (L.) Merill). Weed Science 41:194-200.

58.Wilson, J. R., Wicks, G. A., and Fenter, C. R. (1980).
Weed control in field bean (Phaseolus vulgaris) in Western Nebraska. Weed Science 28: 295 - 299.

59.Wilson, R. G. and Miller, S. D. (1991). Dry edible bean (Phaseolus vulgaris) responses to imazethapyr. Weed Technology 5: 22-26.

60.Yadav, T., Chopra, N. K., Chopra, N. K., Kumar, R., Singh, M., Datt, C., Soni, P. G., Rathore, D. K., and Kumar, S. (2016). Influence of weed control methods on yield and quality of cowpea fodder. Indian Journal of Animal Nutrition 33 (1): 70-74.DOI: 10.5958/2231-6744.216.00 12.8

61.Yadav, T., Chopra, N.K., Chopra, N.K., Kumar, R., and Soni, P.G. (2018). Assessment off critical period of cropweed competition in forage cowpea (Vina unguiculata) and its effect on seed yield and quality. Indian Journal of Agronomy 63(1):124-127. DOI:10.26655/JRWEEDS CI.20 20.2.6 